\title{
Profile of sarilumab and its potential in the treatment of rheumatoid arthritis
}

\author{
This article was published in the following Dove Press journal: \\ Drug Design, Development and Therapy \\ 24 May 2017 \\ Number of times this article has been viewed
}

\author{
Maria Gabriella Raimondo' \\ Martina Biggioggero' \\ Chiara Crotti' \\ Andrea Becciolini ${ }^{2}$ \\ Ennio Giulio Favalli² \\ 'Department of Clinical Sciences \\ and Health Community, Division of \\ Rheumatology, University of Milan, \\ ${ }^{2}$ Department of Rheumatology, \\ Gaetano Pini Institute, Milan, Italy
}

\begin{abstract}
In recent years the use of biotechnological agents has drastically revolutionized the therapeutic approach and the progression of rheumatoid arthritis (RA). In particular, interleukin-6 (IL-6) has been demonstrated as a pivotal cytokine in the pathogenesis of the disease by contributing to both the innate and the adaptive immune system perturbation, and to the production of acute-phase proteins involved in the systemic expression of the disorder. The first marketed IL-6 blocker was tocilizumab, a humanized anti-IL-6 receptor (anti-IL-6R) monoclonal antibody. The successful use of tocilizumab in RA has encouraged the development of other biologic agents specifically targeting the IL-6 pathway, either directed against IL-6 cytokine ( sirukumab, olokizumab, and clazakizumab) or IL-6 receptor (sarilumab). One Phase II and six Phase III randomized controlled trials demonstrated a broad efficacy of sarilumab across all RA patient subtypes, ranging from methotrexate (MTX) to tumor necrosis factor inhibitor insufficient responders. In particular, sarilumab as monotherapy demonstrated a clear head-to-head superiority over adalimumab in MTX-intolerant subjects. In addition, compared with tocilizumab, sarilumab showed a similar safety profile with significantly higher affinity and longer half-life, responsible for a reduction of the frequency of administration (every other week instead weekly). All these aspects may be important in defining the strategy for positioning sarilumab in the treatment algorithm of RA. Indeed, observational data coming from post-marketing real-life studies may provide crucial additional information for better understanding the role of sarilumab in the management of the disease. This review summarizes both the biological role of IL-6 in RA and the clinical data available on sarilumab as an alternative therapeutic option in RA patients.
\end{abstract}

Keywords: rheumatoid arthritis, interleukin-6, sarilumab, monoclonal antibody, biologic drugs

\section{Introduction}

Rheumatoid arthritis (RA) is a chronic autoimmune disease characterized by progressive articular disability, systemic inflammation, and high morbidity. ${ }^{1,2}$ Over the last years, several studies showed that RA pathogenesis is driven by a variety of inflammatory cells together with a complex network of cytokines, leading to both joint destruction and loss of function, and to systemic manifestations, such as fatigue, anemia, osteoporosis, and cardiovascular disorders. ${ }^{3}$ The widespread release of cytokines, including tumor necrosis factor $\alpha$ (TNF $\alpha$ ) and interleukin-6 (IL-6), plays a crucial role in weighing the balance toward a proinflammatory condition, thereby losing the physiological homeostasis. ${ }^{4}$ The current use of biotechnological agents, targeting some of the proinflammatory molecules involved in the autoimmune process, drastically revolutionized the therapeutic approach of RA as well as the natural history of the disease. According to more recent strategies based on a treat-to-target approach, ${ }^{5}$ the combination of methotrexate (MTX) with a biologic disease-modifying anti-rheumatic drug (bDMARD) represents the
Correspondence: Ennio Giulio Favalli Department of Rheumatology, Gaetano Pini Institute, Via Gaetano Pini 9, 20122 Milan, Italy

Tel +390258296421

Fax +39025829 63I5

Email ennio.favalli@gmail.com
Drug Design, Development and Therapy 2017:1। 1593-1603

(c) (1) (8) ๑ 2017 Raimondo et al. This work is published and licensed by Dove Medical Press Limited. The full terms of this license are available at https:/www.dovepress.com/terms.php cc)

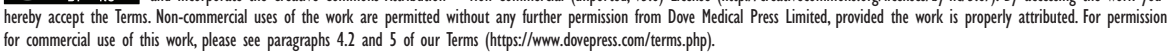


most effective strategy for treating RA refractory to synthetic DMARDs. ${ }^{6,7}$ In particular, TNF $\alpha$ blockade has been the first biotechnological mechanism of action proposed for this indication, and to date TNF inhibitors (TNFis) are the most widely prescribed bDMARDs for the treatment of RA. However, in routine care about $30 \%-40 \%$ of TNFi-treated patients fail to achieve the clinical target, or to maintain over time after an initially good response; or experience adverse events (AEs) leading to treatment withdrawal. ${ }^{8,9}$ As a consequence, the increasing knowledge about RA pathways has focused attention on other potential targets involved in the pathogenesis of the disease, leading to the licensing of bDMARDs with different mechanisms of action such as B-cell depletion, t-cell costimulation inhibition, and IL-6 blockade. In particular, in in vitro studies IL-6 showed a pivotal role in RA autoimmune pathways by contributing to $\mathrm{T}$ - and B-cell activation, autoantibody and acute-phase protein production, and synoviocyte and osteoclast stimulation. ${ }^{10}$ Thus, IL-6 has been implicated in both joint inflammation ${ }^{11}$ and most of the previously mentioned extra-articular manifestations of the disease, such as anemia, ${ }^{12}$ fatigue, ${ }^{13}$ increased cardiovascular risk, ${ }^{14}$ and bone loss. ${ }^{15}$ These findings led to the development of tocilizumab, the first humanized anti-IL-6 receptor (IL-6R) monoclonal antibody, ${ }^{16}$ approved for the treatment of RA after the favorable results of several randomized controlled trials (RCTs) conducted in $\mathrm{TNFi}^{17}$ and MTX insufficient responder patients, both in combination with MTX ${ }^{18-20}$ and as monotherapy. ${ }^{21,22}$ According to international guidelines IL-6 blockade is now recommended as first-line bDMARD treatment in MTX failures, as a consequence of the favorable results of these RCTs and of the subsequent real-life experience, ${ }^{23}$ especially when bDMARD monotherapy is required. ${ }^{24,25}$ The successful use of tocilizumab in RA has encouraged the development of other bDMARDs targeted on IL-6 pathway, either directed against IL-6R ( sarilumab) or IL-6 cytokine ( sirukumab, olokizumab, and clazakizumab).

The aim of this review is to describe the rationale for IL-6 blocking in the management of RA and to analyze the development program for sarilumab, summarizing the evidence in its use for the treatment of the disease.

\section{Role of IL-6 in the pathogenesis of RA}

IL-6 is a pleiotropic cytokine with a proinflammatory activity affecting both the innate and the adaptive immune system. ${ }^{26}$ Evidence suggests that IL-6 increases survival and proliferation of immune cells and helps the shift from acute to chronic inflammation. ${ }^{16,27}$ The cytokine is synthetized by cells of the innate immune arm, such as neutrophils and monocytes, upon toll-like receptor activation with a subsequent widespread diffusion that affects several systems and organs. ${ }^{28}$ In particular, IL-6 induces the secretion of acute-phase proteins, such as C-reactive protein (CRP), by hepatocytes, thereby affecting lipid and glucose metabolism. ${ }^{29}$ Upon IL-6 stimulation endothelial cells release chemokines, which lead to the recruitment of other immune cells and, in concert with other proinflammatory cytokines, to T-cell differentiation and B-cells stimulation. ${ }^{11}$ Indeed, the cytokine promotes antibody production, by causing B-cell maturation, ${ }^{30,31}$ whereas IL-6 together with transforming growth factor- $\beta$ stimulates naïve $\mathrm{T}$ cells to differentiate into $\mathrm{T}$ helper $(\mathrm{Th}) 17$ cells $^{32,33}$ and increases IL-17 production via Th17 cells. ${ }^{34}$ It has been shown that circulating levels of IL-6 are drastically increased during infections or in the contest of other inflammatory conditions, such as autoimmune rheumatic diseases. ${ }^{35,36}$ Patients with RA show elevated concentration of IL- 6 levels both in the serum (ranging from $5 \mathrm{pg} / \mathrm{mL}$ to $200 \mathrm{pg} / \mathrm{mL}$, with $1-16 \mathrm{pg} / \mathrm{mL}$ being the physiologic range in healthy people) and in the synovial fluid (about 100-1,000 fold higher than controls). ${ }^{37-39}$ Serum levels of IL-6 in RA patients correlate with disease severity and radiological joint progression. ${ }^{40,41}$ Then, IL- 6 activates fibroblast-like synoviocytes, which in turn are an important source of the cytokine itself in joint synovia, and it induces autoantibody production by B-cell stimulation. ${ }^{42}$ In vivo studies have showed that IL- 6 is essential for RA pathogenesis. Also, IL-6 injection in in vivo model can induce arthritis, whereas knockout animals are resistant to the disease. ${ }^{43}$ Moreover, a monoclonal antibody to IL-6R reduces disease severity, if administered at an early stage of the disease. ${ }^{44}$

IL-6 is one of the pivotal cytokines involved in the acutephase response, as confirmed by the relation between IL-6 and CRP levels in RA. ${ }^{45}$ These findings, together with the dysregulation of lipid metabolism, correlate IL-6 with an increased cardiovascular risk in RA patients. ${ }^{46,47}$ Moreover, several systemic symptoms such as fever, fatigue, anemia, and systemic osteoporosis are related to an overproduction of the molecule. ${ }^{48-50}$

Finally, the key role of IL-6 in RA pathogenesis has been indirectly confirmed by the successful results obtained from the clinical use of tocilizumab in the treatment of the disease. ${ }^{51,52}$

\section{IL-6 signaling pathway}

The pleiotropic function of IL- 6 finds its realization through the interaction between the cytokine and its receptor, IL-6R. However, the vast majority of human cells do not express IL-6R, which is mainly located on the surface of hepatocytes 
and hematopoietic cells, including T cells, activated B cells, monocytes/macrophages, and neutrophils. ${ }^{53,54}$ IL-6R also exists in a soluble form (sIL-6R), which lacks the transmembrane and cytoplasmic components and is the result of either limited proteolysis of the IL-6R membrane-bound receptor (mIL-6R) or translation from an alternatively spliced mRNA. ${ }^{55}$ sIL-6R is expressed in serum and synovial fluid, inducing a variety of cells, which are not able otherwise, to respond to the IL-6 stimulus. Both soluble and transmembrane IL-6R bind the cytokine with the same affinity. ${ }^{54,56}$ The complex IL-6/IL-6R is able to stimulate cells that constitutionally do not express the receptor by themselves through processes known as trans-signaling, whereas the transduction via the mIL-6R is called cis-signaling (Figure 1) ${ }^{57}$ Studies evaluating the two different pathways were performed with designer proteins in in vivo animal models, showing that cis-signaling is important for regenerative and protective functions of IL-6, whilst the trans-signaling pathway is responsible for the proinflammatory activity of the cytokine. ${ }^{58,59}$ The effective binding between the cytokine and its receptor requires the association with the signal-transducing glycoprotein 130 (gp130) for the initiation of the signaling cascade
A

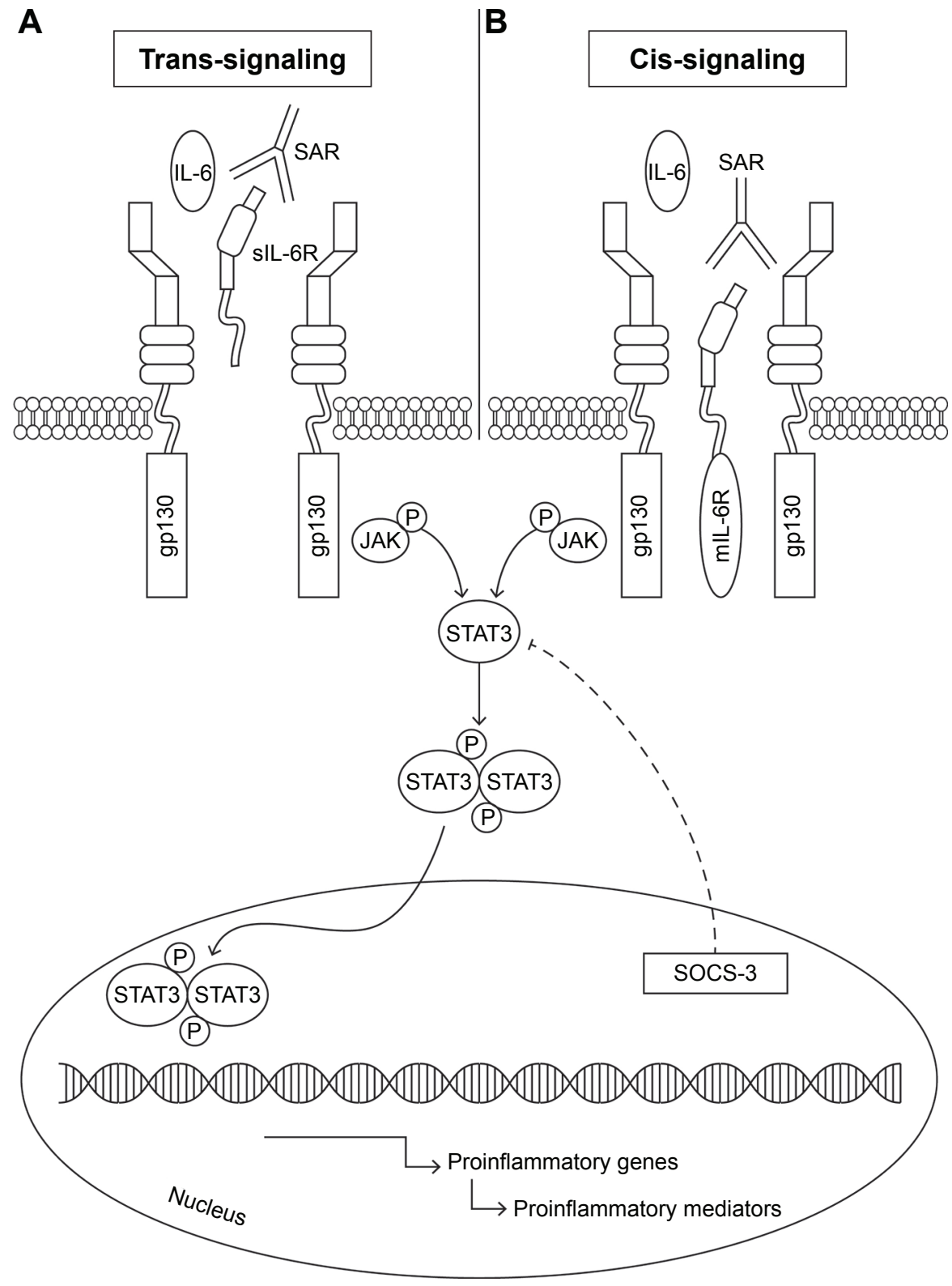

Figure I IL-6 receptor trans and cis-signaling pathway and its blockade by sarilumab.

Abbreviations: gp|30, glycoprotein I30; IL-6, interleukin-6; JAK, Janus family tyrosine kinase; mlL-6R, membrane-bound interleukin-6 receptor; SAR, sarilumab; sIL-6R, soluble interleukin-6 receptor; STAT, signal transducer and activator of transcription; SOCS-3, suppressor of cytokine signaling 3; P, phosphoryl group. 
(Figure 1). ${ }^{56,60}$ Upon interaction with the IL-6/IL-6R complex, dimerization of gp130 leads to a conformational change responsible for the activation of gp130-associated Janus family tyrosine kinases (JAKs), which phosphorylates 5-tyrosine residues located on the cytoplasmic portion of gp130. The membrane-proximal tyrosine stimulates the mitogen-activated protein kinase pathway through the phosphatase SHP2, and the phosphorylation of the other tyrosine residues is responsible for the recruitment of signal transducer and activator of transcription (STAT) factors. The complexes of STAT proteins travel into the nucleus where they stimulate the expression of target genes, including proliferative, anti-apoptotic, and acute-phase protein genes. . $^{56,60}$ Moreover, the expression of suppressor of cytokine signaling 3 protein, a negative regulator of signaling, is upregulated upon activation of the gp130-JAK-STAT pathway as a consequence of IL-6 proinflammatory stimulus. ${ }^{61,62}$ When IL-6 binds to sIL-6R, the complex can interact with any cells that express gp 130, leading to the downstream pathway that happens in cis-signaling described above..$^{56,60}$ Since all cells in the body express gp130, the complex IL-6/sIL-6R could potentially stimulate every cell. In order to avoid this, a soluble non-functional form of gp130 (sgp130) is expressed as a buffer for neutralizing IL-6 activity. Under steady-state condition, levels of sIL-6R and of gp130 are much higher than IL-6, reducing its proinflammatory stimulation. When the cytokine levels are elevated and the buffering capacity is overcome, the surplus of IL- 6 is able to activate the signaling cascade. ${ }^{53,63}$ In addition, IL-6 trans-signaling seems to be involved in the shift from neutrophil to monocyte in the synovial membrane of RA patients and thus in the transition from acute to chronic inflammation. ${ }^{64}$

\section{IL-6 blocking molecules}

Considering the strong evidence of IL-6 involvement in the pathogenesis of RA, the development of agents targeting IL-6 or its receptor gathered significant attention over the last years as new therapeutic option in the treatment of the disease. The first marketed IL-6 blocker was tocilizumab, a humanized anti-IL-6R monoclonal antibody, currently used for managing both MTX and TNFi insufficient responder patients. ${ }^{65}$

Clinical trials and real-life data clearly demonstrate the efficacy of tocilizumab in combination with MTX in producing significant clinical response, in improving physical function, and in preventing radiographic progression. Moreover, tocilizumab monotherapy showed a superior clinical efficacy over MTX monotherapy in the AMBITION trial ${ }^{66}$ and over adalimumab monotherapy in the head-to-head designed
ADACTA trial, ${ }^{22}$ and a similar clinical and radiographic efficacy against the combination with MTX in the ACT-RAY trial. ${ }^{67}$ In addition, tocilizumab exerts significantly great clinical effectiveness in ameliorate systemic manifestations associated with RA as a result of IL-6 overproduction, such as amyloidosis, ${ }^{68,69}$ anemia. ${ }^{12}$ and fatigue. ${ }^{13}$ The pivotal and pleiotropic role of IL-6 in sustaining systemic inflammation is also supported by the efficacy of tocilizumab in the treatment of other conditions such as systemic juvenile idiopathic $\operatorname{arthritis}^{70,71}$ and giant cell arteritis. ${ }^{72,73}$

The unremarkable success of tocilizumab in the treatment of RA led to the more recent development of new biologic agents targeting either IL-6 or IL-6R with higher affinity. Sarilumab is a fully human IgG1 monoclonal antibody that binds to both soluble and membrane-bound IL-6R $\alpha$ with high affinity (Figure 1), thereby interfering with cis- and trans-IL-6-mediated inflammatory pathway. ${ }^{60}$ sarilumab was developed in mice engineered to produce human antibodies with an affinity for the human IL-6R 20 -fold greater than tocilizumab. ${ }^{74}$ Preclinical data on SAR demonstrated a dose-dependent inhibition of IL-6 signaling with lower concentration than tocilizumab and with no evidence of complement-dependent or antibody-dependent cell-mediated cytotoxicity. ${ }^{75,76}$ Efficacy and safety profiles of sarilumab were tested in clinical trials for treatment of patients with active RA, who were unresponsive or intolerant to either previous MTX or TNFi, as described in detail in the following sections in this review. To date, other IL-6 blocking agents are currently under investigation in clinical trials for the treatment of rheumatic diseases. Some of them, such as sirukumab, olokizumab, and clazakizumab, are directly targeted on IL-6, whereas another (ALX-0061) binds to IL-6R, as listed in Table $1 .{ }^{77-83}$ In particular, the latter is an example of the promising application of nanobody technology to the treatment of rheumatic disorders, as already demonstrated for other targets in the pathogenesis of RA such as TNF ${ }^{84}$ and IL-1. ${ }^{85,86}$

\section{Sarilumab for the treatment of RA}

The clinical development program for sarilumab includes one Phase II and six Phase III RCTs, summarized in Table 2, including baseline population characteristics and primary outcomes.

\section{Efficacy of sarilumab in RA}

The MOnoclonal antiBody to IL-6R $\alpha$ In RA patients: a pivotal Trial with X-ray (MOBILITY) is a study program built as an operationally seamless Phase II/III study, part A was the 
Table I IL-6 inhibitors currently investigated for treatment of RA

\begin{tabular}{|c|c|c|c|c|}
\hline Drug & Structure & Target & Clinical trials status (trial registration number) & Study \\
\hline \multirow[t]{3}{*}{ ALX-006I } & Nanobody & sIL-6R mIL-6R & Phase II recruiting (NCT025I8620) & Van Roy et al ${ }^{77}$ \\
\hline & & & Phase II completed (NCT02309359; NCT02287922) & \\
\hline & & & Phase I and II completed (NCT0I284569) & \\
\hline \multirow[t]{3}{*}{ Sirukumab } & Human mAb & IL-6 & Phase III completed (NCT0I689532; NCT02019472; & Zhuang et al $;^{78}$ Smolen et al $;^{79}$ \\
\hline & & & NCT0I604343; NCT0I60676I) & Aletaha et $\mathrm{a}^{80}$ \\
\hline & & & Phase III active, not recruiting (NCT0I856309) & \\
\hline Clazakizumab & Humanized $\mathrm{mAb}$ & IL-6 & Phase II completed (NCT020I5520) & Weinblatt et $\mathrm{a}^{81}$ \\
\hline \multirow[t]{2}{*}{ Olokizumab } & Humanized mAb & IL-6 & Phase III recruiting (NCT02760433; NCT02760368; NCT02760407) & Takeuchi et al; ${ }^{82}$ Genovese \\
\hline & & & Phase II completed (NCT0I5337I4; NCT0I463059) & et $\mathrm{a}^{83}$ \\
\hline
\end{tabular}

Abbreviations: IL-6, interleukin-6; mAb, monoclonal antibody; mIL-6R, membrane interleukin-6 receptor; RA, rheumatoid arthritis; sIL-6R, soluble interleukin-6 receptor.

dose-ranging portion (Phase II), designed as a double-blind, placebo-controlled, multicenter study. ${ }^{87}$ Patients included were aged 18-75 years, had active RA (tender joint count $\geq 8$, swollen joint count $\geq 6$, and CRP $\geq 1 \mathrm{mg} / \mathrm{dL}$ ) of at least 3-month duration despite MTX treatment for a minimum of 12 weeks at a stable dose (10-25 mg/ week) for at least 6 weeks prior to the screening visit. Nonresponders to a previous biologic agent for RA within 3 months before study initiation were excluded. Eligible subjects $(n=306)$ were randomized to receive placebo or one of five subcutaneous sarilumab dosing regimens: $100 \mathrm{mg}$ Q2W, $150 \mathrm{mg}$ Q2W, $200 \mathrm{mg}$ Q2W, $100 \mathrm{mg} \mathrm{QW}$, and $150 \mathrm{mg} \mathrm{QW}$. The primary endpoint (response rate according to American College of Rheumatology 20 [ACR20] criteria) at week 12 was achieved across all doses of $\geq 150 \mathrm{mg}$ Q2W. Furthermore, all four of these drug regimens provided a statistically significant improvements in Disease Activity Score 28 calculated with C-reactive protein (DAS28-CRP) reduction, as well as the exploratory clinical disease activity index (CDAI), ACR50, and ACR70 response rate.

Actually, three Phase III studies involving sarilumab have been published. In MOBILITY part B (Phase III), two separate cohorts of patients $(n=1,285)$ were enrolled. ${ }^{88}$ In cohort 1 (those randomized prior to the Phase III dose selection), patients were randomized to receive placebo or one of five subcutaneous doses of sarilumab $(100 \mathrm{mg}$ weekly, $150 \mathrm{mg}$ weekly, $100 \mathrm{mg}$ every 2 weeks, $150 \mathrm{mg}$ every 2 weeks, or $200 \mathrm{mg}$ every 2 weeks). After the phase III dose selection, patients previously randomized to receive placebo or sarilumab $150 \mathrm{mg}$ or $200 \mathrm{mg}$ every 2 weeks continued the 52-week study, while patients randomized to the other three treatment arms were stopped but were allowed to enter the open-label extension phase in which they received sarilumab at a dose of $200 \mathrm{mg}$ every 2 weeks. In cohort 2 (those randomized after dose selection), patients were randomized (1:1:1) to receive placebo, sarilumab $150 \mathrm{mg}$ every 2 weeks, or sarilumab $200 \mathrm{mg}$ every 2 weeks, in combination with weekly MTX. The efficacy analysis was conducted in the cohort 2 intent-to-treat population. Both sarilumab doses showed statistically significant improvement in all three co-primary endpoints: ACR20 response at week 24 (58.0\% and $66.4 \%$ respectively; $P<0.0001$ ), change in physical function assessed by the Health Assessment Questionnaire-Disability Index (HAQ-DI) at week 16 (least squares mean change -0.53 [sarilumab $150 \mathrm{mg}$ ], -0.55 [sarilumab $200 \mathrm{mg}$ ], and -0.29 [placebo]; $P<0.0001$ for each dose group vs placebo), and radiographic progression of structural damage assessed by change in the modified Sharp/van der Heijde score at week $52(0.9$ [sarilumab $150 \mathrm{mg}$ ], 0.25 [sarilumab $200 \mathrm{mg}$ ], and 2.78 [placebo]; $P<0.0001$ for each dose group vs placebo). Results were favorable for sarilumab and also for all secondary clinical efficacy endpoints, including mean change from baseline of DAS28-CRP and CDAI score, DAS28-CRP remission rate, and ACR50/70 response rate. ${ }^{88}$ After completion of MOBILITY, 901 patients were eligible for enrolment in the open-label extension (OLE) study EXTEND, in which all patients received active treatment (sarilumab $200 \mathrm{mg}$ Q2W after final dose selection) in combination with MTX, showing the durable persistence over a 3-year follow-up period of clinical and radiographic outcomes observed in the double-blind phase, irrespective of prior treatment. ${ }^{89}$

A retrospective analysis was performed on patients from the MOBILITY part A and B, ${ }^{90}$ aiming to evaluate the circulating biomarker levels of bone resorption and synovial inflammation in patients treated with sarilumab $150 \mathrm{mg}$ Q2W or $200 \mathrm{mg}$ Q2W plus MTX. In the MOBILITY part A, collagen type I matrix metalloproteinase (MMP)-cleaved fragment (C1M), collagen type II MMP-cleaved fragment $(\mathrm{C} 2 \mathrm{M})$, collagen type III MMP-cleaved fragment (C3M), and C-reactive protein MMP-derived fragment were the measured biomarkers of tissue destruction and synovial inflammation, whereas serum concentrations of C1M, C2M, C3M, MMP-3, C-terminal telopeptide-1, osteocalcin, 
Table 2 Clinical trials of sarilumab in RA

\begin{tabular}{|c|c|c|c|c|c|}
\hline $\begin{array}{l}\text { Study (trial } \\
\text { registration number) }\end{array}$ & Trial Phase & Drug regimen & Length & Primary endpoint & Study \\
\hline $\begin{array}{l}\text { MOBILITY part A trial } \\
\text { (NCT01061736) }\end{array}$ & Phase II & $\begin{array}{l}\text { Sarilumab } 100 \mathrm{mg} \text { Q2W, } \\
\text { I50 mg Q2W, } 100 \mathrm{mg} \\
\text { QW, } 200 \mathrm{mg} \text { Q2W, } \\
\text { and I } 50 \mathrm{mg} \text { QW SC or } \\
\text { placebo, plus MTX }\end{array}$ & $\begin{array}{l}22 \text { weeks ( } 4 \text { weeks of } \\
\text { screening, } 12 \text { weeks of } \\
\text { treatment, } 6 \text { weeks of } \\
\text { posttreatment follow-up) }\end{array}$ & $\begin{array}{l}\text { ACR20 response rate at } \\
\text { week } 12\end{array}$ & Song et $\mathrm{a}^{84}$ \\
\hline $\begin{array}{l}\text { MOBILITY part B trial } \\
\text { (NCT0I06I736) }\end{array}$ & Phase III & $\begin{array}{l}\text { Sarilumab I50 mg Q2W, } \\
200 \text { mg Q2W SC, or } \\
\text { placebo, plus MTX }\end{array}$ & 52 weeks & $\begin{array}{l}\text { Three co-primary end } \\
\text { points: } \\
\text { I) ACR20 improvement } \\
\text { response at week } 24 \\
\text { 2) change from baseline in } \\
\text { HAQ-DI at week } 16 \\
\text { 3) change from baseline in } \\
\text { the SHS score at week } 52\end{array}$ & Xiang et $\mathrm{a}^{85}$ \\
\hline $\begin{array}{l}\text { TARGET trial } \\
\text { (NCT0I709578) }\end{array}$ & Phase III & $\begin{array}{l}\text { Sarilumab I50 mg Q2W, } \\
200 \text { mg Q2W SC, or } \\
\text { placebo, plus MTX }\end{array}$ & $\begin{array}{l}34 \text { weeks } \\
\text { ( } 4 \text { weeks of screening, } \\
24 \text { weeks of treatment, } \\
6 \text { weeks of follow-up) }\end{array}$ & $\begin{array}{l}\text { Two co-primary end points: } \\
\text { I) ACR20 response at } \\
\text { week } 24 \\
\text { 2) change from baseline in } \\
\text { HAQ-DI at week } 12\end{array}$ & Gabay et $\mathrm{al}^{91}$ \\
\hline $\begin{array}{l}\text { MONARCH trial } \\
\text { (NCT02332590) }\end{array}$ & Phase III & $\begin{array}{l}\text { Sarilumab } 200 \mathrm{mg} \text { Q2W } \\
\text { plus placebo Q2W or } \\
\text { adalimumab } 40 \mathrm{mg} \text { Q2W } \\
\text { plus placebo Q2W }\end{array}$ & 24 weeks & $\begin{array}{l}\text { Change from baseline in } \\
\text { DAS28-ESR at week } 24\end{array}$ & Fleischmann et al ${ }^{94}$ \\
\hline $\begin{array}{l}\text { SARIL-RA-KAKEHASI } \\
\text { (NCT02293902) }\end{array}$ & Phase III & $\begin{array}{l}\text { Sarilumab } 200 \text { mg Q2W } \\
\text { plus MTX or placebo }\end{array}$ & $\begin{array}{l}\text { Up to } 62 \text { weeks ( } 4 \text { weeks } \\
\text { of screening period, } \\
52 \text { weeks of treatment, } \\
\text { and } 6 \text { weeks of post- } \\
\text { treatment) }\end{array}$ & $\begin{array}{l}\text { ACR20 response at } \\
\text { week } 24\end{array}$ & $\begin{array}{l}\text { Study completed, } \\
\text { unpublished data }\end{array}$ \\
\hline $\begin{array}{l}\text { SARIL-RA-HARUKA } \\
\text { (NCT02373202) }\end{array}$ & Phase III & $\begin{array}{l}\text { Sarilumab dose I } \\
\text { Q2W plus non-MTX- } \\
\text { DMARDs, sarilumab } \\
\text { dose } 2 \text { Q2W, sarilumab } \\
\text { dose I Q2W or } \\
\text { sarilumab dose } 2 \text { Q2W }\end{array}$ & $\begin{array}{l}\text { Up to } 62 \text { weeks ( } 4 \text { weeks } \\
\text { of screening period, } \\
52 \text { weeks of treatment, } \\
\text { and } 6 \text { weeks of post- } \\
\text { treatment) }\end{array}$ & $\begin{array}{l}\text { Four co-primary end points } \\
\text { at week } 58 \text { : } \\
\text { I) number of treatment- } \\
\text { emergent adverse events } \\
\text { 2) clinically significant } \\
\text { changes in vital signs } \\
\text { 3) clinically significant } \\
\text { changes in } \\
\text { electrocardiogram } \\
\text { 4) clinically significant } \\
\text { changes in laboratory } \\
\text { values }\end{array}$ & $\begin{array}{l}\text { Study completed, } \\
\text { results not } \\
\text { published yet }\end{array}$ \\
\hline RA-COMPARE & Phase III & $\begin{array}{l}\text { Sarilumab dose I Q2W, } \\
\text { sarilumab dose I } \\
\text { Q2W plus MTX, } \\
\text { sarilumab dose } 2 \text { Q2W, } \\
\text { sarilumab dose } 2 \text { Q2W } \\
\text { plus MTX, etanercept } \\
\text { dose I W, etanercept } \\
\text { dose I W plus MTX, } \\
\text { adalimumab dose I } \\
\text { Q2W, adalimumab } \\
\text { dose I Q2W plus MTX }\end{array}$ & 24 weeks & $\begin{array}{l}\text { Change from baseline in } \\
\text { DAS28-CRP at week } 24\end{array}$ & $\begin{array}{l}\text { This study has } \\
\text { been terminated } \\
\text { for internal } \\
\text { company decision } \\
\text { not related to any } \\
\text { safety issue }\end{array}$ \\
\hline $\begin{array}{l}\text { Open-label extension* } \\
\text { (NCTOI I 46652) }\end{array}$ & $\begin{array}{l}\text { Phase III (open- } \\
\text { label extension) }\end{array}$ & $\begin{array}{l}\text { After dose selection, } \\
\text { patients were switched } \\
\text { to or initiated on } \\
\text { sarilumab } 200 \mathrm{mg} \text { Q2W }\end{array}$ & Up to 523 weeks & $\begin{array}{l}\text { Long-term safety of } \\
\text { sarilumab (incidence and } \\
\text { severity of adverse events) }\end{array}$ & $\begin{array}{l}\text { van der Heijde } \\
\text { et al }{ }^{89}\end{array}$ \\
\hline
\end{tabular}

Notes: *Open-label extension study enrolled RA patients who had completed the MOBILITY and TARGET trials.

Abbreviations: ACR, American College of Rheumatology; CRP, c-reactive protein; DAS28, Disease Activity Score 28; DMARD, disease-modifying anti-rheumatic drug; HAQ-DI, Health Assessment Questionnaire-Disability Index; MTX, methotrexate; RA, rheumatoid arthritis; SC, subcutaneous; SHS, Sharp/van der Heijde score. 
osteoprotegerin (OPG), and soluble receptor activator of nuclear factor-kB ligand (sRANK-L) were measured from MOBILITY part B participating patients. Both sarilumab regimens demonstrated to significantly reduce concentrations of joint inflammation (eg, MMP-3, C1M, and C3M) and induced changes in collagen degradation marker (C2M). Furthermore, sarilumab 200 mg Q2W significantly suppressed bone resorption marker sRANK-L vs placebo $(-28.6 \%$ vs $-10.2 \% ; P<0.01)$, and significantly decreased the sRANK/OPG ratio ( 5 vs 5.4; $P<0.01$ ). Sarilumab, compared with placebo, did not affect serum concentration of OPG. In the end, no statistically significant differences were noted in reduction of several biomarkers in patients who achieved low disease activity compared with those who did not. ${ }^{90}$ In addition, further sub-analyses evaluating change in circulating biomarkers of bone and joint destruction have been performed by comparing patients achieving ACR50 response with no-responders in both MTX and TNFi failures enrolled in MOBILITY and TARGET studies, respectively. Significantly greater reductions in chemokine (C-X-C motif) ligand 13 (a marker of lymphoid RA synovial phenotype), CM1, CRP, and MMP-3 were observed in ACR50 responders relative to nonresponders in the sarilumab-treated group. ${ }^{91,92}$

Moreover, a post hoc analysis of the MOBILITY study has been focused on patient-reported outcomes (PROs). ${ }^{93} \mathrm{In}$ patients treated with sarilumab, improvements in patient global assessment of disease activity, pain visual analog scale and HAQ-DI score, functional assessment of chronic illness therapy-fatigue (FACIT-F), and medical outcomes Short Form-36 (SF-36) appeared already after 2 weeks of therapy and were sustained through week 52. PRO scores with sarilumab $200 \mathrm{mg}$ were generally greater than with sarilumab $150 \mathrm{mg}$ Q2W.

TARGET trial, a three-arm, multicenter, randomized, double-blind, placebo-controlled, Phase III study, investigated ACR20 response at week 24 and HAQ-DI at week 12 in 546 active RA patients insufficiently responder or intolerant to $\geq 1 \mathrm{TNFi}^{94}$ Statistically significant improvement in the ACR20 response was observed in patients receiving sarilumab $150 \mathrm{mg}$ or $200 \mathrm{mg}$ Q2W vs placebo (55.8\% and $60.9 \%$ vs $33.7 \% ; P<0.0001$ ), regardless of the number of prior TNFis. A consensual trend emerged for the mean change from baseline in the HAQ-DI score at week 12 (least squares mean change: for $150 \mathrm{mg}, 20.46$ [ $P=0.0007]$; for $200 \mathrm{mg}, 20.47[P=0.0004])$ vs placebo $(-0.26)$. Similar benefits were observed for secondary clinical outcomes, including ACR50 and ACR70 response, and mean change from baseline in DAS28-CRP score. ${ }^{94}$
A further exploratory analysis comparing efficacy and safety profile of sarilumab according to age ( $\sim$ years) has been performed on a pooled population coming from both MOBILITY part B and TARGET trials. Both sarilumab $150 \mathrm{mg}$ and $200 \mathrm{mg}$ Q2W were superior to placebo in all clinical efficacy scores (ACR20 response, DAS28-CRP remission rate, HAQ-DI score, and CDAI score) at week 24 and in change from baseline in functional evaluation at week 12 in both age groups, without significant difference in elderly subgroup. ${ }^{95}$

The same pooled population was stratified according to baseline characteristics; sarilumab efficacy, measured by ACR20 response and changes in HAQ-DI, DAS28-CRP, and CDAI, was consistent across different subgroups, even if the magnitude of the drug effect was numerically smaller in baseline seronegative subjects for rheumatoid factor or anti-citrullinated peptides autoantibodies, or with a baseline body weight $>100 \mathrm{~kg} .{ }^{96}$

MONARCH was a 24-week multicenter, randomized, active-controlled, double-blind, double-dummy, Phase III superiority trial conducted by comparing sarilumab (200 mg Q2W) and adalimumab monotherapy in patients with active RA who discontinued treatment with MTX due to intolerance or inadequate response. ${ }^{97}$ Mean change from baseline in DAS28-ESR at week 24 (primary endpoint) was significantly higher in sarilumab compared with adalimumab subgroup ( -3.28 vs -2.20 ; difference: -1.08 ; $95 \%$ confidence interval -1.36 to $-0.79 ; P<0.0001)$. Similarly, sarilumab monotherapy demonstrated superiority compared to adalimumab according for all the secondary efficacy endpoints (DAS28-ESR remission rate, ACR20/50/70 responses, mean change from baseline in HAQ-DI, both physical and mental component summary of SF-36, and FACIT-F). ${ }^{97}$

\section{Safety profile of sarilumab in RA}

Overall, sarilumab showed a safety profile consistent with results previously observed with other IL-6 blockers such as tocilizumab.

In MOBILITY part A Phase II trial ${ }^{87}$ the incidence rates of any treatment-emergent adverse events (TEAEs) ranged from $43 \%$ to $72 \%$ in sarilumab groups vs $47 \%$ in the placebo group. The main reasons for sarilumab discontinuation were infections (none classified as serious) and neutropenia. Other changes in laboratory parameters were elevation in transaminases and lipid profile alterations. No dose trend in the incidence of serious adverse events (SAEs) was observed. ${ }^{87}$

In the Phase III part B of the MOBILITY study, ${ }^{88}$ the total exposure (patient-year of treatment) to sarilumab in both subgroups was longer than in the placebo group. ${ }^{88}$ The most 
represented TEAEs were infections, neutropenia, and liver toxicity, all generally mild or moderate in intensity and dose dependent. The incidence of serious infections was aligned to that observed with tocilizumab in RA. ${ }^{42,98,99}$ No cases of tuberculosis, lymphoma, and gastrointestinal perforation occurred. Antidrug antibody development was observed in $16.7 \%, 13.0 \%$, and $2.8 \%$ of patients in the sarilumab $150 \mathrm{mg}$ Q2W, sarilumab $200 \mathrm{mg}$ Q2W, and placebo groups, respectively, without any association with hypersensitivity reactions or inefficacy. ${ }^{88}$

In the TARGET Phase III study, ${ }^{94}$ sarilumab was generally well tolerated. Infections were the most frequently reported TEAEs, but no cases of tuberculosis or systemic disseminated opportunistic infections were observed. SAEs occurred in 5.4\% in sarilumab $200 \mathrm{mg} \mathrm{Q} 2 \mathrm{~W}$ and in 3.3\% in sarilumab $150 \mathrm{mg}$ Q2W and in placebo groups. ${ }^{94}$

In the MONARCH study, overall safety and tolerability of sarilumab and adalimumab monotherapy were generally similar. Incidence of AEs (sarilumab 64.1\% and adalimumab $63.6 \%$ ), SAEs (sarilumab 4.9\% and adalimumab 6.5\%), and infections (sarilumab 28.8\% and adalimumab 27.7\%) were comparable among the two treatment groups. Lipid profile alteration occurred more frequently in the adalimumab group $(4.3 \%)$ than in the sarilumab group $(1.6 \%) .{ }^{97}$ In the pooled explorative analysis from MOBILITY and TARGET trials, incidence of SAEs occurred mostly in the elderly ( $\geq 65$ years of age) group, ${ }^{95}$ without significant differences according to population baseline characteristics. ${ }^{96}$

In the OLE EXTEND study, ${ }^{89}$ long-term sarilumab safety profile was consistent with the one observed in the doubleblind phase, with a stable incidence of TEAEs and SEAEs.

Moreover, in patients experiencing laboratory abnormalities (such as absolute neutrophil count $\geq 0.5-1.0 \mathrm{Giga} / \mathrm{L}$ in the absence of infection, platelet count $\geq 50-100 \mathrm{Giga} / \mathrm{L}$ in the absence of bleeding, or alanine aminotransferase $\geq 3-5$ fold the upper limit of normal), reducing sarilumab dose from $200 \mathrm{mg}$ Q2W to $150 \mathrm{mg}$ Q2W was effective to normalize these parameters allowing study continuation without further complications or efficacy impairment for a mean duration of $>1.5$ years. ${ }^{100}$

Finally, sarilumab has been compared with tocilizumab in terms of safety and tolerability in two studies conducted in RA adult insufficient responders to MTX monotherapy (study 1309 [NCT02097524]) or to a previous TNFi (ASCERTAIN study [NCT01768572]). In both the studies, clinically meaningful AEs were comparable across the treatment groups as well as laboratory changes, suggesting a similar safety profile for IL-6 blockers. ${ }^{101}$

\section{Conclusion}

The crucial role of IL-6 in the pathogenesis of RA and other diseases characterized by profound acute-phase responses, such as Still's disease and giant cell arteritis, is well established and was clearly confirmed by the results of clinical studies evaluating available IL-6 blockers. According to these findings, in a hypothetic cytokine-based disease taxonomy, IL-6 may be considered as a more specific target for treating RA compared with the broad and unspecific effect of TNF blockade. ${ }^{102}$ Tocilizumab has been marketed after a comprehensive development program including studies conducted in all RA subsets and confirmed a favorable efficacy/safety profile in the subsequent post-marketing real-life experience. Sarilumab for RA has been evaluated by a comparable set of RCTs demonstrating a similar broad efficacy across all RA subtypes, from MTX to TNFi insufficient responder patients, showing a clear superiority over adalimumab in the use as monotherapy in MTX-intolerant subjects. Moreover, sarilumab safety profile seemed to be consistent with what expected with IL-6 blockade and previously observed in patients treated with tocilizumab. In addition, from a pharmacodynamic point of view sarilumab showed a significantly higher affinity compared with tocilizumab with a longer half-life, allowing a lower frequency of administration (every other week instead weekly). All these aspects may be important in understanding the position of sarilumab within the class of IL-6 blockers. Moreover, in the very near future, the introduction of several novel potential mechanisms of action (such as Janus kinase inhibition ${ }^{103}$ or GM-CSF blockade ${ }^{104}$ ) or new technologies for drug delivery (such as the application of nanobody technology) may be crucial for better defining the strategy for positioning sarilumab in the treatment algorithm of RA. Indeed, observational data coming from post-marketing real-life studies may provide crucial additional information for better understanding the role of sarilumab in the management of the disease. Moreover, the improvement of individual tailored treatment and the discovery of biomarkers capable of predicting a favorable response to a given drug strategy are needed.

\section{Disclosure}

The authors report no conflicts of interest in this work.

\section{References}

1. McInnes IB, Schett G. The pathogenesis of rheumatoid arthritis. N Engl J Med. 2011;365(23):2205-2219.

2. Smolen JS, Aletaha D, McInnes IB. Rheumatoid arthritis. Lancet. 2016;388(10055):2023-2038.

3. Smolen JS, Aletaha D, Redlich K. The pathogenesis of rheumatoid arthritis: new insights from old clinical data? Nat Rev Rheumatol. 2012; 8(4):235-243. 
4. McInnes IB, Buckley CD, Isaacs JD. Cytokines in rheumatoid arthritisshaping the immunological landscape. Nat Rev Rheumatol. 2016; 12(1):63-68.

5. Smolen JS, Breedveld FC, Burmester GR, et al. Treating rheumatoid arthritis to target: 2014 update of the recommendations of an international task force. Ann Rheum Dis. 2016;75(1):3-15.

6. Carmona L, Cross M, Williams B, Lassere M, March L. Rheumatoid arthritis. Best Pract Res Clin Rheumatol. 2010;24(6):733-745.

7. Scott DL, Wolfe F, Huizinga TW. Rheumatoid arthritis. Lancet. 2010; 376(9746):1094-1108.

8. Marchesoni A, Zaccara E, Gorla R, et al. TNF-alpha antagonist survival rate in a cohort of rheumatoid arthritis patients observed under conditions of standard clinical practice. Ann N Y Acad Sci. 2009; 1173(1):837-846.

9. Favalli EG, Pregnolato F, Biggioggero M, et al. Twelve-year retention rate of first-line tumor necrosis factor inhibitors in rheumatoid arthritis real-life data from a local registry. Arthritis Care Res (Hoboken). 2016;68(4):432-439.

10. Choy E. Understanding the dynamics: pathways involved in the pathogenesis of rheumatoid arthritis. Rheumatology (Oxford). 2012; 51(Suppl 5):v3-v11.

11. Fonseca JE, Santos MJ, Canhão H, Choy E. Interleukin-6 as a key player in systemic inflammation and joint destruction. Autoimmun Rev. 2009;8(7):538-542.

12. Song SN, Tomosugi N, Kawabata H, Ishikawa T, Nishikawa T, Yoshizaki K. Down-regulation of hepcidin resulting from long-term treatment with an anti-IL-6 receptor antibody (tocilizumab) improves anemia of inflammation in multicentric Castleman disease. Blood. 2010; 116(18):3627-3634.

13. Gossec L, Steinberg G, Rouanet S, Combe B. Fatigue in rheumatoid arthritis: quantitative findings on the efficacy of tocilizumab and on factors associated with fatigue. The French multicentre prospective PEPS Study. Clin Exp Rheumatol. 2015;33(5):664-670.

14. Danesh J, Kaptoge S, Mann AG, et al. Long-term interleukin-6 levels and subsequent risk of coronary heart disease: two new prospective studies and a systematic review. PLoS Med. 2008;5(4):e78.

15. Abdel Meguid MH, Hamad YH, Swilam RS, Barakat MS. Relation of interleukin-6 in rheumatoid arthritis patients to systemic bone loss and structural bone damage. Rheumatol Int. 2013;33(3):697-703.

16. Dayer JM, Choy E. Therapeutic targets in rheumatoid arthritis: the interleukin-6 receptor. Rheumatology (Oxford). 2010;49(1):15-24.

17. Emery P, Keystone EC, Tony HP, et al. IL-6 receptor inhibition with tocilizumab improves treatment outcomes in patients with rheumatoid arthritis refractory to anti-tumour necrosis factor biologicals: results from a 24-week multicentre randomised placebo-controlled trial. Ann Rheum Dis. 2008;67(11):1516-1523.

18. Nishimoto N, Miyasaka N, Yamamoto K, Kawai S, Takeuchi T, Azuma J. Long-term safety and efficacy of tocilizumab, an anti-IL-6 receptor monoclonal antibody, in monotherapy, in patients with rheumatoid arthritis (the STREAM study): evidence of safety and efficacy in a 5-year extension study. Ann Rheum Dis. 2009;68(10): $1580-1584$.

19. Smolen JS, Beaulieu A, Rubbert-Roth A, et al; OPTION Investigators. Effect of interleukin-6 receptor inhibition with tocilizumab in patients with rheumatoid arthritis (OPTION study): a double-blind, placebo-controlled, randomised trial. Lancet. 2008;371(9617): 987-997.

20. Kremer JM, Blanco R, Brzosko M, et al. Tocilizumab inhibits structural joint damage in rheumatoid arthritis patients with inadequate responses to methotrexate: results from the double-blind treatment phase of a randomized placebo-controlled trial of tocilizumab safety and prevention of structural joint damage at one year. Arthritis Rheum. 2011;63(3):609-621.

21. Nishimoto N, Ito K, Takagi N. Safety and efficacy profiles of tocilizumab monotherapy in Japanese patients with rheumatoid arthritis: meta-analysis of six initial trials and five long-term extensions. Mod Rheumatol. 2010;20(3):222-232.
22. Gabay C, Emery P, van Vollenhoven R, et al; ADACTA Study Investigators. Tocilizumab monotherapy versus adalimumab monotherapy for treatment of rheumatoid arthritis (ADACTA): a randomised, doubleblind, controlled phase 4 trial. Lancet. 2013;381(9877):1541-1550.

23. Gabay C, Riek M, Hetland ML, et al. Effectiveness of tocilizumab with and without synthetic disease-modifying antirheumatic drugs in rheumatoid arthritis: results from a European collaborative study. Ann Rheum Dis. 2016;75(7):1336-1342.

24. Singh JA, Saag KG, Bridges SL Jr, et al. 2015 American College of Rheumatology Guideline for the treatment of rheumatoid arthritis. Arthritis Rheumatol. 2016;68(1):1-26.

25. Smolen JS, Landewé R, Bijlsma J, et al. EULAR recommendations for the management of rheumatoid arthritis with synthetic and biological disease-modifying antirheumatic drugs: 2016 update. Ann Rheum Dis. Epub 2017 Mar 6.

26. Kishimoto T. IL-6: from laboratory to bedside. Clin Rev Allergy Immunol. 2005;28(3):177-186.

27. Jansen JH, Kluin-Nelemans JC, Van Damme J, Wientjens GJ, Willemze R, Fibbe WE. Interleukin 6 is a permissive factor for monocytic colony formation by human hematopoietic progenitor cells. J Exp Med. 1992;175(4):1151-1154.

28. Chalaris A, Rabe B, Paliga K, et al. Apoptosis is a natural stimulus of IL6R shedding and contributes to the proinflammatory trans-signaling function of neutrophils. Blood. 2007;110(6):1748-1755.

29. Heinrich PC, Castell JV, Andus T. Interleukin-6 and the acute phase response. Biochem J. 1990;265(3):621-636.

30. Muraguchi A, Hirano T, Tang B, et al. The essential role of B cell stimulatory factor 2 (BSF-2/IL-6) for the terminal differentiation of B cells. J Exp Med. 1988;167(2):332-344.

31. Jego G, Bataille R, Pellat-Deceunynck C. Interleukin-6 is a growth factor for nonmalignant human plasmablasts. Blood. 2001;97(6): $1817-1822$.

32. Kimura A, Kishimoto T. IL-6: regulator of Treg/Th17 balance. Eur $J$ Immunol. 2010;40(7):1830-1835.

33. Bettelli E, Carrier Y, Gao W, et al. Reciprocal developmental pathways for the generation of pathogenic effector TH17 and regulatory T cells. Nature. 2006;441(7090):235-238.

34. Veldhoen M, Hocking RJ, Atkins CJ, Locksley RM, Stockinger B. TGFbeta in the context of an inflammatory cytokine milieu supports de novo differentiation of IL-17-producing T cells. Immunity. 2006; 24(2):179-189.

35. Pujhari SK, Prabhakar S, Ratho R, et al. Th1 immune response takeover among patients with severe Japanese encephalitis infection. J Neuroimmunol. 2013;263(1-2):133-138.

36. Usón J, Balsa A, Pascual-Salcedo D, et al. Soluble interleukin 6 (IL-6) receptor and IL-6 levels in serum and synovial fluid of patients with different arthropathies. J Rheumatol. 1997;24(11):2069-2075.

37. Abe H, Sakai T, Ando W, et al. Synovial joint fluid cytokine levels in hip disease. Rheumatology (Oxford). 2014;53(1):165-172.

38. Desgeorges A, Gabay C, Silacci P, et al. Concentrations and origins of soluble interleukin 6 receptor-alpha in serum and synovial fluid. J Rheumatol. 1997;24(8):1510-1516.

39. Hein GE, Köhler M, Oelzner P, Stein G, Franke S. The advanced glycation end product pentosidine correlates to IL- 6 and other relevant inflammatory markers in rheumatoid arthritis. Rheumatol Int. 2005; 26(2):137-141.

40. Dasgupta B, Corkill M, Kirkham B, Gibson T, Panayi G. Serial estimation of interleukin 6 as a measure of systemic disease in rheumatoid arthritis. J Rheumatol. 1992;19(1):22-25.

41. Kishimoto T. Interleukin-6: from basic science to medicine- 40 years in immunology. Annu Rev Immunol. 2005;23:1-21.

42. Navarro-Millán I, Singh JA, Curtis JR. Systematic review of tocilizumab for rheumatoid arthritis: a new biologic agent targeting the interleukin-6 receptor. Clin Ther. 2012;34(4):788-802.e3.

43. Boe A, Baiocchi M, Carbonatto M, Papoian R, Serlupi-Crescenzi O. Interleukin 6 knock-out mice are resistant to antigen-induced experimental arthritis. Cytokine. 1999;11(12):1057-1064. 
44. Takagi N, Mihara M, Moriya Y, et al. Blockage of interleukin-6 receptor ameliorates joint disease in murine collagen-induced arthritis. Arthritis Rheum. 1998;41(12):2117-2121.

45. Madhok R, Crilly A, Watson J, Capell HA. Serum interleukin 6 levels in rheumatoid arthritis: correlations with clinical and laboratory indices of disease activity. Ann Rheum Dis. 1993;52(3):232-234.

46. Kitas GD, Gabriel SE. Cardiovascular disease in rheumatoid arthritis: state of the art and future perspectives. Ann Rheum Dis. 2011;70(1): $8-14$.

47. McInnes IB, Thompson L, Giles JT, et al. Effect of interleukin-6 receptor blockade on surrogates of vascular risk in rheumatoid arthritis: MEASURE, a randomised, placebo-controlled study. Ann Rheum Dis. 2015;74(4):694-702.

48. Rohleder N, Aringer M, Boentert M. Role of interleukin-6 in stress, sleep, and fatigue. Ann N Y Acad Sci. 2012;1261:88-96.

49. Weiss G, Schett G. Anaemia in inflammatory rheumatic diseases. Nat Rev Rheumatol. 2013;9(4):205-215.

50. Edwards CJ, Williams E. The role of interleukin-6 in rheumatoid arthritis-associated osteoporosis. Osteoporos Int. 2010;21(8):1287-1293.

51. Nishimoto N, Yoshizaki K, Maeda K, et al. Toxicity, pharmacokinetics, and dose-finding study of repetitive treatment with the humanized antiinterleukin 6 receptor antibody MRA in rheumatoid arthritis. Phase I/II clinical study. J Rheumatol. 2003;30(7):1426-1435.

52. Choy EH, Isenberg DA, Garrood T, et al. Therapeutic benefit of blocking interleukin-6 activity with an anti-interleukin-6 receptor monoclonal antibody in rheumatoid arthritis: a randomized, double-blind, placebo-controlled, dose-escalation trial. Arthritis Rheum. 2002;46(12): 3143-3150.

53. Rose-John S. IL-6 trans-signaling via the soluble IL-6 receptor: importance for the pro-inflammatory activities of IL-6. Int J Biol Sci. 2012; 8(9): 1237-1247.

54. Rose-John S, Scheller J, Elson G, Jones SA. Interleukin-6 biology is coordinated by membrane-bound and soluble receptors: role in inflammation and cancer. J Leukoc Biol. 2006;80(2):227-236.

55. Mihara M, Hashizume M, Yoshida H, Suzuki M, Shiina M. IL-6/IL-6 receptor system and its role in physiological and pathological conditions. Clin Sci (Lond). 2012;122(4):143-159.

56. Calabrese LH, Rose-John S. IL-6 biology: implications for clinical targeting in rheumatic disease. Nat Rev Rheumatol. 2014;10(12): $720-727$.

57. Heinrich PC, Behrmann I, Haan S, Hermanns HM, Müller-Newen G, Schaper F. Principles of interleukin (IL)-6-type cytokine signalling and its regulation. Biochem J. 2003;374(Pt 1):1-20.

58. Fischer M, Goldschmitt J, Peschel C, et al. I. A bioactive designer cytokine for human hematopoietic progenitor cell expansion. Nat Biotechnol. 1997;15(2):142-145.

59. Jostock T, Müllberg J, Ozbek S, et al. Soluble gp130 is the natural inhibitor of soluble interleukin-6 receptor transsignaling responses. Eur J Biochem. 2001;268(1):160-167.

60. Kim GW, Lee NR, Pi RH, et al. IL-6 inhibitors for treatment of rheumatoid arthritis: past, present, and future. Arch Pharm Res. 2015; 38(5):575-584.

61. Scheller J, Garbers C, Rose-John S. Interleukin-6: from basic biology to selective blockade of pro-inflammatory activities. Semin Immunol. 2014;26(1):2-12.

62. Scheller J, Ohnesorge N, Rose-John S. Interleukin-6 trans-signalling in chronic inflammation and cancer. Scand J Immunol. 2006; 63(5):321-329.

63. Narazaki M, Yasukawa K, Saito T, et al. Soluble forms of the interleukin-6 signal-transducing receptor component gp130 in human serum possessing a potential to inhibit signals through membraneanchored gp130. Blood. 1993;82(4):1120-1126.

64. Gabay C. Interleukin-6 and chronic inflammation. Arthritis Res Ther. 2006;8(Suppl 2):S3.

65. Smolen JS, Landewé R, Breedveld FC, et al. EULAR recommendations for the management of rheumatoid arthritis with synthetic and biological disease-modifying antirheumatic drugs: 2013 update. Ann Rheum Dis. 2014;73(3):492-509.
66. Jones G, Sebba A, Gu J, et al. Comparison of tocilizumab monotherapy versus methotrexate monotherapy in patients with moderate to severe rheumatoid arthritis: the AMBITION study. Ann Rheum Dis. 2009;69(1):88-96.

67. Dougados M, Kissel K, Conaghan PG, et al. Clinical, radiographic and immunogenic effects after 1 year of tocilizumab-based treatment strategies in rheumatoid arthritis: the ACT-RAY study. Ann Rheum Dis. 2014;73(5):803-809.

68. Miyagawa I, Nakayamada S, Saito K, et al. Study on the safety and efficacy of tocilizumab, an anti-IL-6 receptor antibody, in patients with rheumatoid arthritis complicated with AA amyloidosis. Mod Rheumatol. 2014;24(3):405-409.

69. Nishida S, Hagihara K, Shima Y, et al. Rapid improvement of AA amyloidosis with humanised anti-interleukin 6 receptor antibody treatment. Ann Rheum Dis. 2009;68(7):1235-1236.

70. Yokota S, Imagawa T, Mori M, et al. Efficacy and safety of tocilizumab in patients with systemic-onset juvenile idiopathic arthritis: a randomised, double-blind, placebo-controlled, withdrawal phase III trial. Lancet. 2008;371(9617):998-1006.

71. Yokota S, Imagawa T, Mori M, et al. Long-term treatment of systemic juvenile idiopathic arthritis with tocilizumab: results of an open-label extension study in Japan. Ann Rheum Dis. 2013;72(4):627-628.

72. Villiger PM, Adler S, Kuchen S, et al. Tocilizumab for induction and maintenance of remission in giant cell arteritis: a phase 2, randomised, double-blind, placebo-controlled trial. Lancet. 2016; 387(10031):1921-1927.

73. Régent A, Redeker S, Deroux A, et al; French Vasculitis Group, the Groupe Francais pour l'Etude de l'Artérite à Cellules Géantes, and the Club Rhumatismes et Inflammation. Tocilizumab in giant cell arteritis: a multicenter retrospective study of 34 patients. J Rheumatol. 2016;43(8):1547-1552.

74. Rafique A, Martin J, Blome M, Huang T, Ouyang A, Papadopoulos N. Evaluation of the binding kinetics and functional bioassay activity of sarilumab and tocilizumab to the human IL-6 receptor (IL-6R) alpha [abstract]. Ann Rheum Dis. 2013;72(Suppl 3):797.

75. Genovese MC, Fleischmann RM, Fiore S, Radin AR, Fan C, Huizinga TW. Sarilumab, a subcutaneously-administered, fully-human monoclonal antibody inhibitor of the IL-6 receptor: relationship between EULAR responses and change from baseline of selected clinical parameters [abstract]. Ann Rheum Dis. 2013;72(Suppl 3):620.

76. Wang LH, Xue Y, Liu X, et al. Preclinical development of sarilumab, the first fully-human monoclonal antibody $(\mathrm{mAb})$ against IL-6R alpha: utilization and value of double humanized animal model [abstract]. Ann Rheum Dis. 2013;72(Suppl 3):375.

77. Van Roy M, Ververken C, Beirnaert E, et al. The preclinical pharmacology of the high affinity anti-IL-6R Nanobody ${ }^{\circledR}$ ALX-0061 supports its clinical development in rheumatoid arthritis. Arthritis Res Ther. 2015;17(1):135.

78. Zhuang Y, de Vries DE, Xu Z, et al. Evaluation of disease-mediated therapeutic protein-drug interactions between an anti-interleukin- 6 monoclonal antibody (sirukumab) and cytochrome P450 activities in a phase 1 study in patients with rheumatoid arthritis using a cocktail approach. J Clin Pharmacol. 2015;55(12):1386-1394.

79. Smolen JS, Weinblatt ME, Sheng S, Zhuang Y, Hsu B. Sirukumab, a human anti-interleukin-6 monoclonal antibody: a randomised, 2-part (proof-of-concept and dose-finding), phase II study in patients with active rheumatoid arthritis despite methotrexate therapy. Ann Rheum Dis. 2014;73(9):1616-1625.

80. Aletaha D, Bingham CO 3rd, Tanaka Y, et al. Efficacy and safety of sirukumab in patients with active rheumatoid arthritis refractory to anti-TNF therapy (SIRROUND-T): a randomised, double-blind, placebo-controlled, parallel-group, multinational, phase 3 study. Lancet. 2017;389(10075):1206-1217.

81. Weinblatt ME, Mease P, Mysler E, et al. The efficacy and safety of subcutaneous clazakizumab in patients with moderate-to-severe rheumatoid arthritis and an inadequate response to methotrexate: results from a multinational, phase IIb, randomized, double-blind, placebo/active-controlled, dose-ranging study. Arthritis Rheumatol. 2015;67(10):2591-2600. 
82. Takeuchi T, Tanaka Y, Yamanaka H, et al. Efficacy and safety of olokizumab in Asian patients with moderate-to-severe rheumatoid arthritis, previously exposed to anti-TNF therapy: results from a randomized phase II trial. Mod Rheumatol. 2016;26(1):15-23.

83. Genovese MC, Fleischmann R, Furst D, et al. Efficacy and safety of olokizumab in patients with rheumatoid arthritis with an inadequate response to TNF inhibitor therapy: outcomes of a randomised Phase IIb study. Ann Rheum Dis. 2014;73(9):1607-1615.

84. Song J, Chen Y, Jiang S, et al. Efficient and non-toxic biological response carrier delivering TNF- $\alpha$ shRNA for gene silencing in a murine model of rheumatoid arthritis. Front Immunol. 2016;7:305.

85. Xiang S, Su J, Tong H, et al. Biscarbamate cross-linked low molecular weight PEI for delivering IL-1 receptor antagonist gene to synoviocytes for arthritis therapy. Biomaterials. 2012;33(27):6520-6532.

86. Liang D, Fu X, Liao M, Yuan W, Su J. Development of dextran microparticles loaded with IL-1Ra of high-encapsulation efficiency and high-bioactivity by a novel method without exposing IL-1Ra to water-oil interfaces. Powder Technol. 2013;235:299-302.

87. Huizinga TW, Fleischmann RM, Jasson M, et al. Sarilumab, a fully human monoclonal antibody against IL-6R $\alpha$ in patients with rheumatoid arthritis and an inadequate response to methotrexate: efficacy and safety results from the randomised SARIL-RA-MOBILITY Part A trial. Ann Rheum Dis. 2014;73(9):1626-1634.

88. Genovese MC, Fleischmann R, Kivitz AJ, et al. Sarilumab plus methotrexate in patients with active rheumatoid arthritis and inadequate response to methotrexate: results of a phase III study. Arthritis Rheumatol. 2015;67(6):1424-1437.

89. van der Heijde D, van Adelsberg J, van Hoogstraten H, et al. Clinical and radiographic outcomes after 3 years of sarilumab in patients with rheumatoid arthritis [abstract]. Arthritis Rheumatol. 2016;68(Suppl 10).

90. Boyapati A, Msihid J, Fiore S, van Adelsberg J, Graham NM, Hamilton JD. Sarilumab plus methotrexate suppresses circulating biomarkers of bone resorption and synovial damage in patients with rheumatoid arthritis and inadequate response to methotrexate: a biomarker study of MOBILITY. Arthritis Res Ther. 2016;18(1):225.

91. Gabay C, Msihid J, Daskalakis N, et al. Effect of sarilumab on circulating biomarkers of bone and joint destruction in patients with rheumatoid arthritis with inadequate response to methotrexate [abstract]. Arthritis Rheumatol. 2016;68(Suppl 10).

92. Gabay C, Msihid J, Daskalakis N, Barbot A, Zilberstein M, Boyapati A. Effect of sarilumab on circulating biomarkers of bone and joint destruction in patients with rheumatoid arthritis with previous inadequate response to tumor necrosis factor inhibitors [abstract]. Arthritis Rheumatol. 2016;68(Suppl 10).
93. Strand V, Kosinski M, Chen CI, et al. Sarilumab plus methotrexate improves patient-reported outcomes in patients with active rheumatoid arthritis and inadequate responses to methotrexate: results of a phase III trial. Arthritis Res Ther. 2016;18:198.

94. Fleischmann RM, van Adelsberg J, Lin Y, et al. Sarilumab and nonbiologic disease-modifying antirheumatic drugs in patients with active rheumatoid arthritis and inadequate response or intolerance to tumor necrosis factor inhibitors. Arthritis Rheumatol. 2017; 69(2):277-290

95. Fleischmann R, Genovese MC, van Adelsberg J, et al. Pooled safety and efficacy of sarilumab in rheumatoid arthritis patients 65 years of age and older [abstract]. Arthritis Rheumatol. 2016;68(Suppl 10).

96. Genovese MC, Fleischmann R, Mangan E, et al. Efficacy and safety of sarilumab in subgroups of patients with rheumatoid arthritis from 2 phase 3 studies [abstract]. Arthritis Rheumatol. 2016;68(Suppl 10).

97. Burmester GR, Lin Y, Patel R, et al. Efficacy and safety of sarilumab monotherapy versus adalimumab monotherapy for the treatment of patients with active rheumatoid arthritis (MONARCH): a randomised, double-blind, parallel-group phase III trial. Ann Rheum Dis. 2017;76(5):840-847.

98. Navarro G, Taroumian S, Barroso N, Duan L, Furst DE. Tocilizumab in rheumatoid arthritis: a meta-analysis of efficacy and selected clinical conundrums. Semin Arthritis Rheum. 2014;43(4):458-469.

99. Schett G, Elewaut D, McInnes IB, Dayer JM, Neurath MF. How cytokine networks fuel inflammation: toward a cytokine-based disease taxonomy. Nat Med. 2013;19(7):822-824.

100. Genovese MC, Rubbert-Roth A, Smolen JS, et al. Longterm safety and efficacy of tocilizumab in patients with rheumatoid arthritis: a cumulative analysis of up to 4.6 years of exposure. J Rheumatol. 2013; 40(6):768-780.

101. Genovese MC, Fay J, Parrino J, et al. Sarilumab dose reduction in an open-label extension study in RA patients [abstract]. Arthritis Rheumatol. 2016;68(Suppl 10).

102. Emery P, Rondon J, Garg A, et al. Safety and tolerability of subcutaneous sarilumab compared to intravenous tocilizumab in patients with RA [abstract]. Arthritis Rheumatol. 2015;67(Suppl 10).

103. Semerano L, Decker P, Clavel G, Boissier MC. Developments with investigational Janus kinase inhibitors for rheumatoid arthritis. Expert Opin Investig Drugs. 2016;25(12):1355-1359.

104. Crotti C, Raimondo MG, Becciolini A, Biggioggero M, Favalli EG Spotlight on mavrilimumab for the treatment of rheumatoid arthritis: evidence to date. Drug Des Devel Ther. 2017;11:211-223.

\section{Publish your work in this journal}

Drug Design, Development and Therapy is an international, peerreviewed open-access journal that spans the spectrum of drug design and development through to clinical applications. Clinical outcomes, patient safety, and programs for the development and effective, safe, and sustained use of medicines are the features of the journal, which

\section{Dovepress}

has also been accepted for indexing on PubMed Central. The manuscript management system is completely online and includes a very quick and fair peer-review system, which is all easy to use. Visit http://www.dovepress.com/testimonials.php to read real quotes from published authors. 